Andrzej R y k

ORCID: 0000-0001-8120-3982

Uniwersytet Pedagogiczny im. Komisji Edukacji Narodowej w Krakowie

\section{Doświadczenie wspólnoty osób jako źródła przezwyciężania chaosu aksjonormatywnego wspótczesnego świata. Rozważania w perspektywie koncepcii Dietricha von Hildebranda}

\author{
The Experience of the Community of People \\ as a Source of Overcoming \\ the Axionormative Chaos of the Modern World: \\ Reflections from the Perspective \\ of Dietrich von Hildebrand
}

\section{ABSTRAKT}

Artykuł przedstawia analizę wybranych myśli Dietricha von Hildebranda w perspektywie ukazania wspólnoty osób jako źródła przezwyciężania chaosu aksjonormatywnego. Centralnymi kategoriami, wokół których prowadzone sq rozważania, sq: osoba, wspólnota, poznanie, świat wartości, kryzys i chaos. W koncepcii fenomenologa świat, zarówno ten w wymiarze ontycznym, jak i ten w wymiarze aksjologicznym, nie jest ani dziełem przypadku, ani nie nosi cech chaosu. Jest uporzqdkowany i hierarchiczny. Osoba jako istota rozumna i wolna posiada pełne zdolności, aby ów porzq̨dek nie tylko prawidłowo odczytać, ale również na bazie tego ontycznego i normatywnego ładu budować uporzqdkowane życie indywidualne i zbiorowe w różnych wymiarach.
SLOWA KLUCZOWE osoba, wspólnota, wartość, kryzys, chaos

\section{KEYWORDS}

person, community, value, crisis, chaos

SPI Vol. 21, 2018/4

ISSN 2450-5358

e-ISSN 2450-5366 DOI: 10.12775/SPI.2018.4.001

Nadestano: 29.08.2018 Zaakceptowano: 10.12.2018

Artykuły i rozprawy 


\section{ABSTRACT}

The article presents an analysis of the selected thoughts of Dietrich von Hildebrand from the perspective of showing the community of people as a source of overcoming axionormative chaos. The central categories around which the considerations are conducted are: the person, community, cognition, the world of values, crisis and chaos. In the phenomenologist's concept, the world, both in the ontic and axiological dimensions, is neither accidental nor chaotic but orderly and hierarchical. A person as a rational and free creature has full abilities, so that this order can not only be read correctly, but also on the basis of this ontic and normative order to build an orderly individual and collective life in various dimensions.

\section{Wrowadzenie - tożsamość osoby}

Celem artykułu jest ukazanie możliwości przełamania kryzysu aksjonormatywnego w oparciu o doświadczenie wspólnoty osób. Za punkt wyjścia w swoich rozważaniach przyjmuję wybrane ujęcia myśli Dietricha von Hildebranda ${ }^{1}$ - jednego ze współtwórców filozoficznej szkoły fenomenologii, bezpośredniego ucznia i kontynuatora myśli Edmunda Husserla².

Kluczową kategorią, którą należy rozważyć w tak przyjętej perspektywie, jest „osoba”. Postawmy więc fundamentalne pytanie: kim jest „osoba”? W perspektywie myśli fenomenologicznej Hildebranda jest ona przede wszystkim swoistym „światem samym w sobie”, czy też „bytem samym w sobie”. Co to oznacza? Hildebrand odwołuje się w tym miejscu do tradycji - klasycznej filozofii realistycznej, dla której podstawowymi kategoriami są: celowość i sensowność tego, co istnieje. Osoba jawi się tu jako najwyższa forma substancji w materialnym porządku świata.

1 Szerzej na temat sylwetki filozoficznej D. von Hildebranda w: P. Mazanka, J. Sidorek, Kim byt Dietrich von Hildebrand?, w: D. von Hildebrand, Czym jest flozofia?, przeł. P. Mazanka, J. Sidorek, Kraków 2012, s. 9-25.

2 Więcej na temat kontynuatorów myśli Husserla w mojej pracy: A. Ryk, $W$ poszukiwaniu podstaw pedagogiki humanistycznej. Od fenomenologii Edmunda Husserla do pedagogiki fenomenologicznej, Kraków 2011. 
Człowiek jest osobą. Jest świadomą, obdarzonym własnym „ja”, spoistą $\mathrm{w}$ sobie, posiadającą samą siebie, wolną istotą. Refleksja nad tą specyficzną cechą ukazuje nam całkowicie nowe, znacznie głębsze warstwy istnienia, z którą mamy tu do czynienia, i pozwala nam poznać ogromną różnicę względem substancji materialnych i witalnych również pod względem sposobu wyrażenia właściwego substancji „bycia dla siebie”.

W powyższym fragmencie odnajdujemy specyficzne cechy bycia osobą. Najpierw więc świadomość, obdarzenie siebie własnym „ja”, wewnętrzną spoistość, jedność osobową, zdolność do „posiadania” samego siebie oraz wolność. Przyjrzyjmy się bliżej poszczególnym wyznacznikom „bycia osobą”, aby pełniej odczytać jej istotę.

Okazuje się więc, że osoba jest istotą świadomą. Co to jednak znaczy? Świadomość nierozerwalnie wiąże się zarówno ze światem, który nas otacza, ale zarazem również z jakimś rodzajem świata wewnętrznego, którego każdy z nas jest nosicielem. Kolejne pytanie, które się rodzi, dotyczy jeszcze innego problemu: czy świadomość jest jakąś pochodną samego rozumu, ludzkiej racjonalności, a może również jest sprawą serca, uczuć, emocji ? W jednej ze swych prac Hildebrand pisał:

Prawdziwa świadomość [...] oznacza [...], że intencjonalny, celowościowy stosunek do bytu bierze górę nad wszystkim, co ma charakter jedynie skojarzeniowy lub też uwarunkowany przez oddziaływania fizyczne. Ludzie nieświadomi są zdani na wszelkie wrażenia przypadkowe ${ }^{5}$.

Świadomość jest więc nierozerwalnie związana ze światem poznawanych (doświadczanych) przedmiotów. Mogą one jednak mieć różną, czasami bardzo specyficzną naturę. Mogą to być przedmioty materialne, symboliczne, osobowe, duchowe, religijne itp. Świadomość człowieka staje się więc w jakimś sensie wypadkową w całej swej złożoności, procesu poznania a zarazem rozpoznawania rzeczywistości jako takiej w jej wielowymiarowym charakterze. Każdy z doświadczanych przedmiotów posiada własną, specyficzną naturę, strukturę, funkcje, logikę, która w ten czy inny sposób staje się

3 D. von Hildebrand, Metafizyka wspólnoty. Rozważania nad istota i wartościa wspólnoty, przeł. J. Zychowicz, Kraków 2012, s. 39.

4 Por. D. von Hildebrand, Serce. Rozważania o uczuciowości ludzkiej i uczuciowości Boga-Człowieka, przeł. J. Koźbiał, Poznań 1985.

5 D. von Hildebrand, Przemienienie w Chrystusie, przeł. J. Zychowicz, Kraków 1982, s. 51. 
rozpoznaną treścią naszej świadomości. Świadomość narasta wraz z bogactwem doznań i przeżyć. I dlatego w konsekwencji:

Stan czuwania człowieka świadomego oznacza jednak zarazem pełniejsze przeżywanie swojego życia. [...], dopiero człowiek świadomy rzeczywiście rozumie wartości, rozpoznaje ich zasadnicze żądanie i wyraźnie na nie odpowiada. Aprobata oznacza $z$ moralnego punktu widzenia nie tylko istotne, głębokie sformułowanie odpowiedzi na wartość, lecz także o wiele bardziej świadome jej spełnienie ${ }^{6}$.

Świadomość nie jest więc wyizolowaną formą świata, ale staje się jakąś formą mnie samego, staje się tożsamością mojego własnego, indywidualnego i w pełni subiektywnego "ja”. "Ja" materialne, będące „bytem w sobie”, posiada równocześnie ,ja świadomościowe”, będące indywidualnym „byciem w sobie” a zarazem jakimś „byciem dla siebie”. Ta umiejętność przechodzenia od „bycia w sobie” do „bycia wobec” - czy też „dla siebie” - jest według Hildebranda kolejną cechą charakteryzującą osobę ludzką. To, innymi słowy, zdolność do prowadzenia swoistego wewnętrznego dialogu w relacji podmiot - przedmiot, toczonego jednak zawsze w obrębie tej samej osoby.

Jeszcze innym predykatem wyróżniającą osobę jest wolność. Dla Hildebranda, w odróżnieniu od różnorakich form zniewoleń, takich jak: egocentryzm, drażliwość, wstręt, kompleks niższości, nieuzasadniona obawa przed ludźmi, nadmierne uleganie wpływom, zbyt duża zależność od opinii publicznej, kompleks niezależności itp.:

[...] prawdziwa wolność jest przeciwieństwem stoickiego ideału ataraksji i apatii, przy którym stajemy się niewrażliwi na wszelkie dobra, a więc, będąc panem sytuacji, pozbywamy się wszelkich więzi. Prawdziwa wolność nie czyni nas bowiem niewrażliwymi ani na cierpienia, ani na dobrodziejstwa zsyłane przez Boga; prawdziwe wartości przejmują nasze serce o wiele głębiej i silniej, jesteśmy bowiem wolni od wszelkich irracjonalnych, nieuzasadnionych, krępujących nas więzów?

\section{Duchowa styczność miedzy osobami}

Ludzka wolność jest więc nierozerwalnie związana z prawdą, jaką daje się jej odczytać. Osoba ludzka występuje w określonym „porządku rzeczy", jej życie ma swój cel i sens. Rodzi się swoista triada:

6 Tamże, s. 56.

7 D. von Hildebrand, Przemienienie w Chrystusie, dz. cyt., s. 219. 
poznanie - prawda - wolność. Wydaje się, że w filozoficznej myśli Hildebranda te trzy rzeczywistości stanowią określoną jedność. Rozpatrywanie każdej z nich osobno tylko wówczas ma sens, jeśli czynimy to w perspektywie dwóch pozostałych kategorii. Prawdziwa wolność człowieka jest odpowiedzią jego serca na codzienne wydarzenia jego życia.

A jednak osoba ludzka, która jak żadna inna znana nam z doświadczenia istota stworzona stanowi świat dla siebie, dopiero w styczności duchowej z innymi osobami, w łączności z nimi, krótko mówiąc: dopiero we wspólnocie w szerszym sensie tego słowa, znajduje spełnienie swoich istotnych skłonności ${ }^{8}$.

Czym jest owa „duchowa styczność” dwóch osób? Podążając za rozważaniami Hildebranda, jest rodzajem wzajemnego przenikania się światów duchowych (światów doświadczanych i przeżywanych) ,ja i ty". Owo wzajemne przenikanie może posiadać różną intensywność, dynamikę, a w konsekwencji w nieco odmienny sposób tworzyć zalążki osobowej wspólnoty. Obok ,ja - ty” pojawia się swoista relacja „my”.

Obok prawzoru ,ja - ty” mamy prawzór „my”. [...]. Kiedy dwoje ludzi wspólnie coś przeżywa, [...], to dla każdego z nich świadomość współobecności drugiej osoby oznacza istotną modyfikację w porównaniu z sytuacją, w której przeżywa on coś analogicznego zupełnie sam. $\mathrm{W}$ tej świadomości, że drugi człowiek przeżywa to samo, zawiera się swoista z nim styczność - przede wszystkim czysto intencyjna. Fakt, że drugi człowiek jest „tu oto dla mnie”, że jego obecność zabarwia moje przeżywanie, modyfikuje je, [...] nawet jeśli nie wie on nic o mojej obecności ${ }^{9}$.

W tym swoistym, często dramatycznym wzajemnym przenikaniu się ,ja - ty” rodzi się wspólnota „my”. Poprzez „styczność”, „zespolenie” następuje „zjednoczenie”, ,ja - ty” w „my”.

Hildebrand wyróżnia kilka stopni styczności. Najniższy polega na tym, że się ukierunkowujemy intencyjnie na inne osoby. Kolejny stopień „styczności” zachodzi wówczas, kiedy nie tylko ukierunkowujemy się na drugą osobę, ale również jej o tym „oznajmiamy”. Owo oznajmienie jednak może być w różnoraki sposób odebrane.

8 D. von Hildebrand, Metafizyka wspólnoty. Rozważania nad istota i wartościa wspólnoty, dz. cyt., s. 40 .

9 Tamże, s. 51. 
Najpierw możemy zostać niezrozumiani, odtrąceni, a w końcu z akceptującą miłością przyjęci w pełnym znaczeniu tego słowa ${ }^{10}$.

Z kolei warunkiem „zespolenia”, ,ja - ty” jest pozytywna natura oznajmianej postawy. Jakiś rodzaj wzajemnej afirmacji, jakiegoś „,ruchu ku sobie", wzajemnego zainteresowania się sobą, wzajemnego i odwzajemnionego „wejrzenia w siebie”. $Z$ pozycji „bycia obok siebie” przechodzimy na pozycje „bycia dla siebie”. Ta forma bycia ma przede wszystkim charakter duchowy, choć elementy czasu i przestrzeni, indywidualnych „egzystencjalnych trajektorii życiowych” mogą odgrywać znaczącą rolę modyfikującą we wzajemnym „zespoleniu"11.

\section{Od zespolenia do zjednoczenia}

Zespolenie, które wprawdzie stanowi całkiem nowy stopień uczestnictwa w bycie, przekraczający formalny punkt szczytowy styczności duchowej, nie jest jednak bynajmniej punktem szczytowym możliwych związków miedzy osobami, [...]. Punkt ten zostaje osiągnięty dopiero w zjednoczeniu ${ }^{12}$.

Hildebrand wymienia podstawowe warunki, jakie muszą nastąpić, aby doszło do „zjednoczenia” ,ja - ty”. Przede wszystkim każdy akt „zjednoczenia” musi nastąpić w określonej sferze wartości. $\mathrm{Na}$ szczycie hierarchii wartości w danej sferze wartości musi stać miłość:

Tylko w takiej miłości, w której druga osoba stoi przede mną jako wypełniona wartością aż do najgłębszej warstwy swej egzystencji, w której akceptuję ją nie tylko jako miły twór, lecz także jako drogocenne naczynie duchowe z jego tajemniczym stosunkiem do Boga, zanika owa dysharmonia miedzy formalną intencją miłości a jej materialną jakością ${ }^{13}$.

Miłość jako ostateczna forma „zjednoczenia” jawi się więc jako nadrzędna wartość, z jednej strony pobudzona przez drugą osobę, a z drugiej jako wypływająca z obiektywnej sfery wartości, w której zarówno ja sam, jak i druga osoba uczestniczymy. Sprawą kluczową dla „zjednoczenia” jest uczestnictwo w świecie wartości, w którym

\footnotetext{
10 Por. tamże, s. 41-49.

11 Por. tamże, s. 50-55.

12 Por. tamże, s. 56.

13 Tamże, s. 113.
} 
centralną rolę odgrywa Bóg, jako zasadnicze spoiwo podtrzymujące trwałość doświadczenia i przeżywania „zjednoczenia”. Prawdziwe „zjednoczenie" jest możliwe tylko wtedy, kiedy rozgrywa się w sferze wartości religijnych.

Każda miłość, która nie jest inkorporowana w religijnej sferze wartości, cierpi na tę wewnętrzną rozbieżność. Jest ona miłością, która „utknęła” [...]. Miłość do drugiego człowieka w Bogu nie jest miłością „wysublimowaną", lecz jedyną w pełni dorosłą, dojrzałą do rozwinięcia formalnej intencji miłości w ogóle. Każda miłość, która nie dochodzi do akceptacji najwyższego dobra drugiego człowieka i jego umiłowania w Bogu, jest miłością „przekreśloną”, niezdolną sprostać swej własnej intencji ${ }^{14}$.

\section{Zjednoczenie jako uczestnictwo w świecie wartości}

Uczestnictwo $\mathrm{w}$ świecie wartości oraz trwanie w zjednoczeniu z drugą osobą sprawia, że otwieramy się w pełni również na inne osoby. W antropologii Hildebranda osoba ludzka jako istota duchowa posiada stronę „zewnętrzną” i „wewnętrzną”. Kiedy to, co „wewnętrzne” jest zamknięte, uśpione (z różnych powodów), to stykamy się z innymi tylko stroną „zewnętrzną”, przywdziewamy maski i gramy role - rodzinne, zawodowe, społeczne. Akt zjednoczenia z drugą osobą, poprzez otwarcie na miłość i uczestnictwo w sferze obiektywnych wartości, otwiera również naszą stronę „wewnętrzną”.

Kiedy skorupa obojętności, egoizmu, pychy, utworzona na zewnętrznej stronie człowieka i zamykająca go wobec innych, topnieje w zetknięciu ze światem wartości, kształtuje się jednocześnie więź ze wszystkimi innymi ludźmi (oczywiście pod warunkiem, że nie wyrzekły się one same w sposób metafizycznie ostateczny tego świata i nie odgrodziły się od niego - przyp. Hildebrand). Dotarcie w głąb osoby, która zostaje urzeczona tym doniosłym samym w sobie, stojącym ponad wszelką dowolnością otwierającym się ponad nami promiennym królestwem wartości, jest zarazem usunięciem istniejących dotąd „między” osobami barier ${ }^{15}$.

14 Tamże, s. 114.

15 Tamże, s. 117. 


\section{Od tożsamości osoby do tożsamości wspólnoty}

Pod wpływem silnych bodźców płynących ze świata wartości nawiązuje się, poprzez przebudzenie owej wewnętrznej strony naszego „ja", swoista więź z innymi osobami - rodzi się wspólnota. Oczywiście nie jest to sytuacja jednorazowa, nagła, spontaniczna. Jest to cały proces, zamknięty w kreślonym ciągu zdarzeń, dziejący się w perspektywie określonego czasu i przestrzeni. Osoba wpisana w ten ciąg zdarzeń niejako mimochodem odkrywa świat nowych doznań, relacji i możliwości, jakie daje otwarcie się na świat wartości i drugiego człowieka. Jednak sama wspólnota podtrzymująca swą tożsamość dzięki sensotwórczemu uczestnictwu w obiektywnym porządku wartości może - dla Hildebranda - przybierać zróżnicowane formy od wspólnot dwuosobowych, np. w małżeństwie do wspólnot wieloosobowych, jak np. państwo, naród itp. Ale co sprawia, że dana grupa, społeczność tworzy wspólnotę? Hildebrand zauważa, że:

[...] nie wszyscy ludzie związani jakąś relacją, tworzą eo ipso również wspólnotę. Istnieje np. wielu ludzi zaprzyjaźnionych, którzy jednak nie konstytuują osobnego tworu wspólnotowego; $\mathrm{z}$ drugiej strony wielu ludzi w pewnych wspólnotach jest już związanych ze sobą jako człony całości, zanim jeszcze przeżyją wzajemną relację [...]. Widzimy zatem, że tam, gdzie występuje wspólnota, osoby są obiektywnie i realnie połączone w nową realną całość - tworzą w jej składzie nową jednostkę, np. rodzinę, państwo, naród itp. ${ }^{16}$

Podążając za myślą Hildebranda, spróbujmy „zajrzeć” niejako do wnętrza samej wspólnoty i wydobyć $z$ niej najbardziej charakterystyczne cechy, które pozwoliłyby lepiej określić, a zarazem zrozumieć tożsamość samej wspólnoty. Po pierwsze, odróżnia on wspólnotę od jedności nierealnych w ten sposób, że wspólnota nie jest tylko grupą osób posiadającą określone cechy, np. wzrost, wykształcenie, miejsce zamieszkania itp., ale zawsze składa się z konkretnych osób, jako swoistych „części składowych” samej wspólnoty. Osób posiadających swój własny świat doświadczany i przeżywany, osób rozumianych jako istoty duchowe. W konsekwencji dla Hildebranda wspólnota staje się nie rodzajem „zbiorowości”, ale nową obiektywną, realnie istniejącą jednostką, posiadającą swą stronę zewnętrzną i wewnętrzną.

Tamże, s. 139. 
Do tego co zewnętrzne we wspólnocie należy jej struktura, forma, wszystkie cechy o charakterze socjologicznym. Na wnętrze wspólnoty składają się relacje, doświadczenia i przeżycia międzyosobowe dziejące się w perspektywie obiektywnego porządku wartości tych, którzy stanowią jej osobowy skład. W wyniku prowadzonych analiz

[...] coraz dobitniej okazywało się, że im bardziej wspólnota jest rzeczywiście wspólnotą, im bardziej jest autentyczną całością, w której ludzie są prawdziwie zespoleni, tym ważniejsza jest w jej obrębie konstytutywna sfera wartości. Można wręcz powiedzieć, że tylko twory wspólnotowe ukonstytuowane na zasadzie sfery wartości są wspólnotami w pełnym znaczeniu ${ }^{17}$.

Jak jednak należy rozumieć owo „ukonstytuowanie wspólnoty na zasadzie sfery wartości”? Interpretując analizy Hildebranda nie można mieć wątpliwości, że chodzi mu przede wszystkim o zakorzenienie - zarówno życia jednostkowego, osobowego, jak i życia zbiorowego, wspólnotowego - w obiektywnym, sensownym, hierarchicznym porządku wartości. Stąd również same wspólnoty mają również charakter hierarchiczny.

\section{Podsumowanie i wnioski}

Dotychczasowe rozważania można podsumować następująco. Dla fenomenologa na poziomie ontologii świat istnieje realnie, ma swego Stwórcę, sens, cel, hierarchiczną strukturę i określony porządek bytowy. Idąc dalej, ów świat jest poznawalny na drodze aktów duchowych, rozumianych jako akty intuicji ejdetycznej, tzn. docierające do istoty danej rzeczy. W związku z tym pochodną samego realnie istniejącego świata i możliwości jego poznania, przez doświadczanie i przeżywanie, jest istnienie obiektywnej sfery wartości, niejako wypływającej z owego świata. Osoba ludzka jako swoisty fenomen realnie istniejącego świata, będąca zarówno „światem w sobie”, „wobec” i „dla siebie”, staje się również światem dla drugiego człowieka, dla drugiej osoby. Owo „bycie dla drugiego” przybiera różnorakie wyrazy i formy. Zakorzenienie owego „bycia dla drugiego” w obiektywnie istniejącej i właściwie odczytanej sferze wartości ma wartość sensotwórczą i wspólnototwórczą. To rodzaj, jak pisze Hildebrand: „inkorporacji 
osób w sferze wartości”. Im głębsze zakotwiczenie osób w owej sferze, tym silniejsza więź rodząca i podtrzymująca istnienie wspólnoty.

Postawmy obecnie pytanie o najbardziej charakterystyczne cechy tytułowego aksjonormatywnego kryzysu, o jego źródła. Pozostając w kręgu myśli fenomenologicznej, chciałbym przywołać fragment rozważań Edmunda Husserla, którego myśli kontynuował i rozwijał Hildebrand:

I ja jestem pewien, że kryzys europejski ma swe korzenie w zbłąkanym racjonalizmie. Ale nie wolno sądzić, że racjonalność, jako taka jest zła, albo też, że w całości egzystencji ludzkiej ma ona znaczenie jedynie podrzędne. Racjonalność w [...] sensie, o jakim tu mówimy, w sensie pierwotnie greckim, który w klasycznym okresie greckiej filozofii stał się ideałem, z pewnością wymagałby jeszcze wiele wyjaśnień autorefleksyjnych [...]. $\mathrm{Z}$ drugiej strony chętnie przyznajemy, [...] że postać racjonalizmu oświeceniowego, który ratio przybrała w toku swego rozwoju, była zbłąkaniem ${ }^{18}$.

Upraszczając, chodzi tu przede wszystkim o odwrócenie dotychczasowego sposobu doświadczania i interpretowania świata rzeczy, poprzez tzw. „przewrót kopernikański” Kanta i cały nurt filozofii pokartezjańskiej ${ }^{19}$. To nie świat rzeczy nadaje sens naszemu poznaniu, kształtuje ratio, ale nasze poznanie (ratio) staje się sensotwórcze. Obiektywny, sensowny i celowy porządek rzeczy zostaje podważony. To sam poznający podmiot staje się kreatorem rzeczywistości. Wielość poznawczych perspektyw, wielość i różnorodność interpretacji,

18 E. Husserl, Kryzys europejskiego cztowieczeństwa a filozofia, przeł. J. Sidorek, Warszawa 1993, s. 38.

19 Znaną interpretację tego faktu odnajdujemy u Jana Pawła II w pracy: Pamięć i tożsamość, Kraków 2005, s. 16-17: „Cogito, ergo sum - myślę, więc jestem, przyniosło odwrócenie porządku $\mathrm{w}$ dziedzinie filozofowania. W okresie przedkartezjańskim filozofia, a więc cogito (myślę) czy raczej cognosco (poznaję), było przyporządkowana do esse (być), które było czymś pierwotnym. Dla Kartezjusza natomiast esse stało się czymś wtórnym, podczas, gdy za pierwotne uważał cogito. W ten sposób dokonała się nie tylko zmiana filozofowania, ale również radykalne odejście od tego, czym dawniej była filozofia [...]. Wcześniej wszystko było interpretowane przez prymat istnienia esse i wszystko się przez ten pryzmat tłumaczyło. Bóg jako samoistne istnienie [...] stanowił nieodzowne oparcie dla [...] wszystkich bytów stworzonych, a więc także dla człowieka. (...). Od Kartezjusza nauka staje się nauką czystego myślenia: wszystko to, co jest bytem (esse) - zarówno świat stworzony jak i Stwórca - pozostaje w polu Cogito - jako treść ludzkiej świadomości. Filozofia zajmuje się bytami o tyle, o ile są treścią świadomości, a nie o tyle, o ile istnieją poza nią". 
uzależnionych od przestrzennych i czasowych (historycznych) kontekstów tworzy wiele odmiennych od siebie, a czasem i wykluczających się narracji i dyskursów. Trudności w epistemologiczno-aksjologicznym porządkowaniu świata nawarstwiają chaos i zagubienie. Pojawia się człowiek późnej nowoczesności ${ }^{20}$, człowiek bez właściwości ${ }^{21}$, człowiek w poszukiwaniu sensu ${ }^{22}$, człowiek maszyna ${ }^{23}$, a w opinii niektórych następuje koniec człowieka ${ }^{24}$ itp.

W takiej perspektywie zadajmy pytanie dotyczące możliwości aplikacji filozoficznej myśli Hildebranda do procesu przezwyciężenia chaosu aksjonormatywnego współczesnego świata. Punktem kluczowym wydaje się tu być przekonanie o realności istnienia zarówno świata jako takiego, jak i samego podmiotu jako nieodzownej części samej rzeczywistości. Ów hierarchiczny porządek rzeczy na poziomie ontycznym sprawia, że sam podmiot $z$ jednej strony staje się częścią tego porządku a $z$ drugiej nie neguje to możliwości i sensowności poznania jako takiego. Odrzuca więc już na początku wszelkie formy czy to agnostycyzmu, czy też defetyzmu epistemologicznego.

Skoro świat, który poznajemy, posiada swój sens i cel, to również ludzkie poznanie jawi się jako działanie celowe i sensowne, i to zarówno w wymiarze zbiorowym (społecznym), jak i w wymiarze subiektywnym (indywidualnym). Odkrywanie a zarazem odczytywanie obiektywnego porządku rzeczy staje się źródłem porządkowania idei o świecie w różnych wymiarach i ramach: filozoficznym, nauk szczegółowych, społecznym, czy też egzystencjalnym (osobowym). Rodzi się określona struktura wartości (systemy, hierarchie) będąca pochodną podejmowanych wysiłków poznawczych człowieka. Ratio odzyskuje swe oparcie i siłę w realności obowiązywania samego świata i odzyskuje swe poznawcze zdolności, dzięki przekonaniu nie o swojej mocy i absolutyzacji własnego "ego", ale dzięki oparciu o logos rozpoznawany $\mathrm{w}$ procesie dia-logosu z otaczającym światem. Ów dialog jest możliwy

Ch. Delsol, Esej o człowieku późnej nowoczesności, przeł. M. Kowalska, Kraków 2003.

21 R. Musil, Cztowiek bez właściwości, przeł. K. Radziwiłł, K. Truchanowski, J. Zeltzer, Warszawa 2002.

22 V.E. Frankl, Cztowiek w poszukiwaniu sensu, przeł. A. Wolnicka, Warszawa 2009.

23 J.O. La Mettrie, Cztowiek maszyna, przeł. S. Rudniański, Warszawa 1984.

24 F. Fukuyama, Koniec cztorwieka, przeł. B. Pietrzyk, Kraków 2004. 
właśnie dzięki szeroko rozumianej wspólnocie: podmiotu z samym sobą, podmiotu $\mathrm{z}$ rozpoznawanym przedmiotem - podmiotu $\mathrm{z}$ rozpoznawanym innym podmiotem, podmiotem doświadczającym i przeżywającym swe własne życie a zarazem życie świata we wspólnocie osób, podmiocie rozpoznającym swe miejsce w opus creationis.

\section{Bibliografia}

Delsol Ch., Esej o cztowieku późnej nowoczesności, przet. M. Kowalska, Znak, Kraków 2003.

Frankl V.E., Cztowiek w poszukiwaniu sensu, przeł. A. Wolnicka, Wydawnictwo Czarna Owca, Warszawa 2009.

Fukuyama F., Koniec cztowieka, przeł. B. Pietrzyk, Znak, Kraków 2004.

Hildebrand D. von, Czym jest filozofia?, przeł. P. Mazanka, J. Sidorek, Wydawnictwo WAM, Kraków 2012.

Hildebrand D. von, Metafizyka wspólnoty. Rozważania nad istota i wartościa wspólnoty, przeł. J. Zychowicz, Wydawnictwo WAM, Kraków 2012.

Hildebrand D. von, Przemienienie w Chrystusie, przeł. J. Zychowicz, Znak, Kraków 1982.

Hildebrand D. von, Serce. Rozważania o uczuciowości ludzkiej i uczuciowości Boga-Cztowieka, przeł.J. Koźbiał, W Drodze, Poznań 1985.

Husserl E., Kryzys europejskiego cztowieczeñstwa a filozofia, przel. J. Sidorek, Aletheia, Warszawa 1993.

Jan Paweł II, Pamię́ i tożsamość, Znak, Kraków 2005.

La Mettrie J.O., Cztowiek maszyna, przeł. S. Rudniański, PWN, Warszawa 1984.

Mazanka P., Sidorek J., Kim byt Dietrich von Hildebrand?, w: D. von Hildebrand, Czym jest filozofia?, przeł. P. Mazanka, J. Sidorek, Wydawnictwo WAM, Kraków 2012, s. 9-25.

Musil R., Cztowiek bez wtaściwości, przeł. K. Radziwiłł, K. Truchanowski, J. Zeltzer, Państwowy Instytut Wydawniczy, Warszawa 1971.

Ryk A., W poszukiwaniu podstaw pedagogiki humanistycznej. Od fenomenologii Edmunda Husserla do pedagogiki fenomenologicznej, Oficyna Wydawnicza „Impuls”, Kraków 2011.

\section{ADRES DO KORESPONDENCJI}

Dr hab. Andrzej Ryk, prof. UP

Uniwersytet Pedagogiczny im. Komisji Edukacji Narodowej w Krakowie Wydział Pedagogiczny Instytut Nauk o Wychowaniu

e-mail: andrzej.ryk@up.krakow.pl 